\begin{tabular}{|l|l|}
\hline JURNAL ABDI MASYA & Volume 1 No 2 \\
& Mei 2021 \\
E-ISSN : 2774-2849 & We 92-102 \\
P-ISSN : 2774-2881 & Website : https://jurnal.sttw.ac.id/index.php/abma/about \\
\hline
\end{tabular}

\title{
PENINGKATAN KUALITAS JURU LAS BENGKEL LAS RUMAH TANGGA MELALUI PELATIHAN DAN SERTIFIKASI
}

\section{QUALITY IMPROVEMENT OF HOUSEHOLD WELDER THROUGH TRAINING AND CERTIFICATION}

\author{
Sukmaji Indro Cahyono ${ }^{1}$, Nurul Muhayat ${ }^{2}$, Triyono $^{3 *}$ \\ ${ }^{1}$ Prodi Teknik Mesin, Fakultas Teknik, Universitas Sebelas Maret Surakarta \\ *Email: triyono74@staff.uns.ac.id
}

\begin{abstract}
ABSTRAK
Banyak juru las industri rumah tangga yang bisa mengelas secara otodikdak namun tidak menguasai teknik pengelasan yang sesuai standard yang ditetapkan oleh asosiasi pengelasan. Untuk itu, tim pengabdian kepada masyarakat Jurusan Teknik Mesin Universitas Sebelas Maret Surakarta bekerja sama dengan Inlastek Welding Institute Surakarta malaksanakan pelatihan juru las untuk meningkatkan mutu produk bengkel las rumah tangga. Pelaksanaan pelatihan pengelasan ini dilakukan dengan standard ISO 9606-1-2013. Pelatihan pengelasan ini dilakukan selama 2 hari di mana materi pelatihan teori diajarkan oleh tim pengabdi UNS karena mempunyai sertifikat Welding Engineer sedangkan materi pelatihan praktek dan uji sertifikasi dilakukan di Inlastek Welding Institute. Hasil pelatihan menunjukkan bahwa ada peningkatan kemampuan pengelasan terutama pengelasan dalam mengelas pelat yang tebal. Selain itu, juru las juga menjadi mengenal jenis-jenis teknik pengelasan yang lebih canggih daripada teknik pengelasan yang ada di bengkelnya.
\end{abstract}

Kata Kunci : juru las; sertifikasi; ISO 9606-1; bengkel las

\begin{abstract}
Many domestic industrial welders can weld independently but do not master welding techniques according to the standards set by the welding association. For this reason, the community service team of the Department of Mechanical Engineering, Sebelas Maret University, Surakarta, in collaboration with the Inlastek Welding Institute Surakarta, conducted welder training to improve the quality of household welding workshop products. The implementation of this welding training was carried out with the ISO 9606-1-2013 standard. This welding training was carried out for 2 days in which the theoretical training material was taught by the UNS service team because it had a Welding Engineer certificate while the practical training material and certification tests were carried out at the Inlastek Welding Institute. The results of the training show that there is an increase in welding ability, especially welding in welding thick plates. Also, the welder becomes acquainted with the types of welding techniques that are more sophisticated than the welding techniques in his workshop.
\end{abstract}

Keywords: welder; certification; ISO 9606-1; welding workshop Submit : 24 Maret 2021, Revision : 29 April 2021, Accepted: 3 Mei 2021,
Published: 28 Mei 2021

\section{PENDAHULUAN}

Segmen pasar pada usaha bengkel las di berbagai wilayah tergolong sama yaitu produk yang digunakan pada sektor perumahan, seperti pagar, teralis jendela, pintu pagar, 
tangga dan lain-lain. Karena varian produk yang sedikit, maka bengkel las tersebut kadang kebanjiran order tapi di lain waktu sepi dari order. Persaingan usaha sangat ketat karena jumlah bengkel las yang sangat banyak sedangkan jumlah konsumen terbatas. Sebagai contoh kasus, di wilayah desa Jaten Kabupaten Karanganyar, selain banyak terdapat perumahan juga menjadi sentra industri menengah dan gudang. Segmen pasar bengkel las di perumahan adalah pagar, tralis dan kanopi, sedangkan segmen pasar di gudang industri adalah membuat konstruksi bangunan gudang tersebut. Konstruksi bangunan gudang sebagian besar menggunakan konstruksi baja yang dilas. Namun hingga saat ini, bengkel las tersebut sebagian besar baru mengerjakan segmen pasar yang dari perumahan dan belum pernah mengerjakan segmen pasar konstruksi bangunan gudang atau industri karena mereka belum memiliki sertifikat juru las yang standar dan belum pernah mempunyai pengalaman dalam rancang bangun konstruksi gudang/industri. Selain itu, juru las tersebut bisa mengerjakan pekerjaan pengelasan dengan belajar secara otodikdak atau magang pada suatu bengkel las sebelumnya, bukan melalui pelatihan di badan pelatihan juru las resmi (Authorized Training Body/ATB) [1] sehingga mempunyai beberapa kelemahan antara lain:

a. Pengetahuan secara teori mengenai sifat material selama pengelasan lemah.

b. Pengetahuan juru las tentang perancangan sambungan las kurang.

c. Mutu dan faktor keamanan sambungan las belum bisa dipertanggungjawabkan secara teknik.

d. Produk hasil pengelasan pada suatu konstruksi belum teruji secara standar sehingga jika mendapat order pekerjaan konstruksi yang mengandung resiko keamanan akan sangat membahayakan.

e. Belum mempunyai sertifikat las, juru las dan bengkel las Sumber Rejeki ini mempunyai daya saing yang rendah. Bengkel las ini juga jarang mendapat order pekerjaan untuk konstruksi yang besar seperti konstruksi pabrik atau gudang. Padahal banyak sekali pabrik dan gudang berdiri di sekitar tempat bengkel las Sumber Rejeki ini sebagaimana telah dijelaskan di analisis situasi.

f. Juru las belum memahami gambar kerja konstruksi las yang mengandung simbolsimbol pekerjaan las, sehingga jika mendapat pekerjaan yang berdasarkan gambar teknik, juru las belum bisa membaca gambar tersebut.

g. Juru las tidak memahami perilaku material selama pengelasan, sehingga sering melakukan proses produksi yang salah yang dapat menurunkan sifat mekanik sambungan las, misalnya setelah mengelas, sambungan las langsung siram air agar cepat mendingin.

Oleh karena itu, pelatihan untuk para juru las industri rumah tangga sangat penting untuk dilakukan. Dengan pelatihan dan sertifikasi, mereka diharapkan mempunyai skill/keterampilan yang standard dan mempunyai pemahaman tentang perilaku material selama proses pengelasan. Dengan kombinasi keterampilan dan pemahaman, maka mutu produk industri bengkel las rumah tangga bisa meningkat.

\section{METODE}

Pelatihan dan sertifikasi untuk juru las bengkel las rumah tangga dilaksanakan dengan sasaran sebagai berikut:

a. Menstandarkan keterampilan juru las.

Melaksanakan pelatihan Standarisasi juru las adalah dengan memberikan training pengelasan pada lembaga taining standard yang diakui oleh Asosiasi Pengelasan Indonesia (API) bahkan merupakan Authorized Training Body yang diakui asosiasi pengelasan dunia seperti IIW (Eropa) dan AWS (Amerika). 
Keterampilan juru las yang standard dapat menghasilkan suatu produk konstruksi yang mengandung resiko keamanan yang tinggi dan kuat, misalkan konstruksi atap, akan terjamin keamanannya secara teknik. Selain itu, dalam melaksanakan pekerjaan seorang juru las akan senantiasa sadar akan mutu dan standar operasi sehingga secara langsung kontrol kualitas sambungan las akan terjaga secara berkelanjutan [2].

b. Mensertifikasikan juru las.

Memberikan ujian standarisasi dan bagi juru las yang lolos akan mendapatkan sertifikasi juru las. Diharapkan dengan memiliki sertifikasi pada Juru las akan meningkatkan daya saing. Apalagi sertifikat juru las yang didapat adalah berstandar ISO 9606-1. Juru las yang memiliki sertifikat akan mampu bersaing dalam persaingan yang cukup ketat. Pertimbangan dan keuntungan dengan adanya sertifikat juru las adalah sebagai berikut; seseoarang yang memiliki sertifikat akan lebih diutamakan oleh pelanggan dan memiliki percaya diri yang tinggi dalam menjalankan meraih pangsa pasar yang lebih luas dan mampu mengerjakan proyek-proyek skala besar, tidak lagi hanya mengandalkan proyek-proyek kecil yang berupa pagar, tralis dan kanopi. Secara tidak langsung bila proyek-proyek besar dapat diraih maka, bengkel las akan membuka lapangan kerja yang baru dan lebih banyak bagi warga sekitar bengkel las.

c. Memberi penjelasan dan pemahaman tentang gambar kerja teknik pengelasan dan sifat berikut fenomena material selama proses pengelasan berlangsung.

Desain struktur rangka atau produk yang dibuat melalui proses pengelasan secara teknik dinyatakan dalam gambar teknik terlebih dahulu. Gambar teknik standard ISO tersebut memuat simbol-simbol pengerjaan proses pengelasan. Juru las yang belum tersertifikasi belum mengetahui gambar teknik dan symbol pengelasan sehingga ketika mendapat pekerjaan proyek besar dan ada gambar tekniknya mereka tidak memahami makna simbol-simbol tersebut pengerjaan proses pengelasan tersebut. Simbol-simbol gambar teknik tersebut mengandung syarat-syarat persiapan, pelaksanaan dan pasca proses pengelasan serta dimensi/ukuran dan toleransi geometri sambungan las. Jika gambar teknik tidak dipahami oleh juru las, maka struktur las yang dibuat memiliki kualitas yang buruk, tidak sesuai dengan standar yang diminta pelanggan dan bahkan bisa membahayakan orang lain. Selain itu, sifat material yang dilas akan mengalami siklus perubahan panas, hal itu dimulai dengan pemanasan, mencair dan membeku [3]. Kecepatan pendinginan selama pengelasan akan sangat mempengaruhi sifat material yang di ukur dengan kekuatan mekanik sambungan las dan sifat lainnya [4]. Karena pemahaman yang kurang terhadap sifat material selama pengelasan menyebabkan banyak juru las yang melakukan tindakan yang dapat menurunkan sifat mekanik sambungan las, misalkan dengan meyiramkan air setelah pengelasan.

Tahapan-tahapan pelaksanaan pelatihan dan sertifikasi pengelasan adalah seperti terlihat pada Gambar 1 dengan penjelasan sebagai berikut:

Tahap I adalah pelatihan juru las dengan teori sifat material selama pengelasan, desain konstruksi las dan proses pengelasan. Tim PKM UNS akan menjadi nara sumber dalam pelatihan ini. Tim PKM mempunyai sertifikat Welding Engineer dan Welding Inspector dari Japan Welding Engineer Society (JWES) dan sudah sering menjadi pemateri dalam program sertifikasi pengelasan yang diselenggarakan oleh Asosiasi Pengelasan Indonesia (API). Setelah selesai tahap pemberian materi teori tentang sifat material selama pengelasan dan desain struktur las, maka peserta dapat mengikuti training (praktek) mengelas. 
Tahap II adalah pelatihan dan sertifikasi di Authorized Training Body (ATB) resmi untuk mendapat sertifikasi pengelasan standar ISO 9606-1 yaitu di INLASTEK Surakarta dengan posisi 1G (mendatar) dan diakhiri dengan ujian sertifikasi las. Dalam ujian ini, juru las tidak selalu lulus ujian karena ketatnya penilaian. Jika tidak lulus ujian maka ada remidi/mengulang tanpa biaya. Dalam sertifikasi juru las, PKM ini wajib menggandeng mitra pelaksana karena UNS bukan lembaga sertifikasi juru las sehingga tidak berhak mengeluarkan sertifikat juru las.

Tahap III adalah praktek pelatihan las dengan membuat kanopi besar di depan masjid Fatimah Ar-Royyan Jongkang dengan dana pendamping dari mitra ke 3 yaitu Takmir Masjid Fatimah Ar-Royyan. Kanopi ukuran 35 x 7 x 5 meter didesain oleh Tim PKM UNS dengan melibatkan juru las yang telah disertifikasi untuk semakin memantapkan pemahaman tentang symbol las dalam gambar teknik. Rancangan gambar dan model kanopi yang akan digunakan sebagai materi training sekaligus digunakan oleh mitra ketiga ditampilkan pada Gambar 2.

\begin{tabular}{|ll}
\hline TAHAP III & $\begin{array}{l}\text { - MENERAPKAN PEMAHAMAN } \\
\bullet \text { MEMBUAT KANOPI BERSAMA }\end{array}$ \\
\hline TAHAP II & $\begin{array}{l}\bullet \text { WORKSHOP PENGELASAN } \\
\bullet \text { UJIAN SERTIFIKASI JURU LAS }\end{array}$ \\
\hline TAHAP I & $\bullet$ PELATIHAN JURU LAS \\
\hline
\end{tabular}

Gambar 1. Tahapan dalam pelaksanaan pengabdian masnyarakat

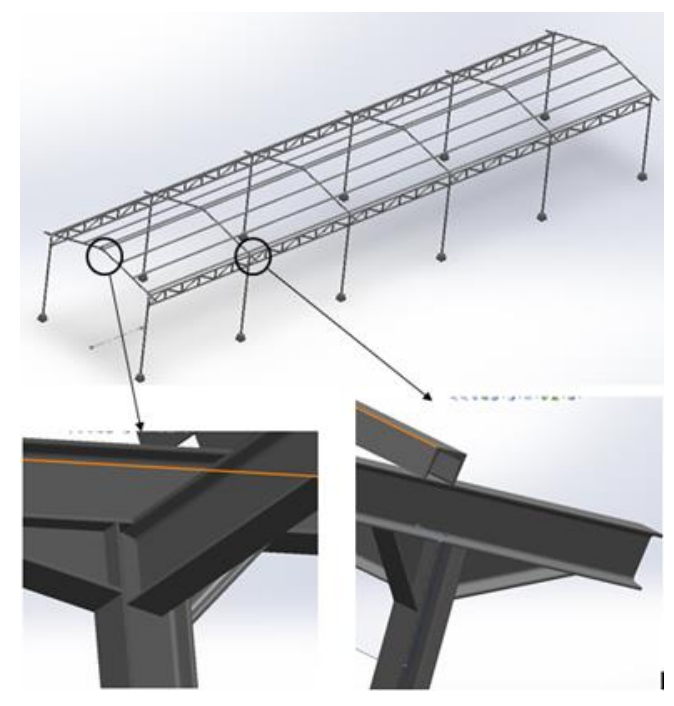

Gambar 2. Rencana model konstruksi las.

\section{HASIL DAN PEMBAHASAN}

Sesuai dengan tahapan pelaksanaan pengabdian yang direncanakan, langkah pertama adalah memberi materi teori pengelasan kepada peserta pelatihan teknologi pengelasan. Teori ini sangat penting karena semua peserta yang ikut dalam pelatihan ini belum ada yang pernah mendapatkan teori teknik pengelasan. Mereka bisa mengelas logam namun teori teknik pengelasan tidak mengetahui. Materi teori pengelasan dilakukan dalam 
setengah hari (5 jam) dengan kegiatan seperti terlihat pada Gambar 3 dan dengan materi antara lain adalah:

a. Teknik-teknik pengelasan yang sering digunakan dalam bengkel dan industri umum.

Teknik-teknik pengelasan yang paling popular untuk bengkel las umumnya adalah teknik las elektroda terbungkus (shielded metal arc welding) karena harganya yang relative murah [5]. Khusus untuk jenis teknik las ini diulas sangat rinci meliputi parameter-parameter pengelasan berdasarkan mesin lasnya (missal arus listrik, tegangan listrik), parameter-parameter pengelasan berdasarkan prosesnya (kecepatan pengelasan, sudut elektroda) dan parameter-parameter pengelasan berdasarkan elektrodanya (diameter elektroda, jenis fluks pembungkus).

Teknik pengelasan lain yang juga cukup popular adalah teknik pengelasan semi otomatis metal gas (Gas Metal Arc Welding). Mesin las jenis ini cukup mahal sehingga hanya bengkel-bengkel las menengah ke atas yang mampu mengadakannya. Mesin las ini semi otomatis, dimana elektroda las berupa gulungan kawat yang bias keluar sendiri jika gun las dinyalakan. Kelebihan mesin las ini bias mengelas panjang tanpa harus berhenti mengganti elektroda.

Teknik las ketiga yang disampaikan ke peserta adalah teknik las tungsten (Gas Tungsten Arc Welding). Orang awam sering menyebut dengan las argon atau las aluminium, karena memang sering digunakan untuk mengelas material aluminium dan menggunakan gas pelindung yang berupa argon.

b. Perilaku material selama proses pengelasan.

Pada pelaksanaan pelatihan ini, baru material baja yang menjadi topik pelatihan karena baja adalah material yang paling banyak diaplikasikan dalam kehidupan sehari-hari. Material lainnya, seperti aluminium, tembaga, dan lain-lain belum bisa disampaikan dalam pelatihan ini mengingat waktu yang sangat singkat. Pemahaman seorang juru las terhadap perilaku material pada saat dilas adalah sangat penting. Selama proses pengelasan, material yang dilas mengalami siklus termal dari dingin menjadi panas bahkan mencair kemudian mendingin dan beku. Siklus termal ini akan sangat mempengaruhi karakteristik material yang dilas, sehingga pengetahuan tentang perubahan sifat material akibat proses pengelasan sangat penting bagi para juru las.

c. Desain sambungan las dan simbol pengelasan dalam gambar teknik.

Dalam dunia teknik, gambar teknik merupakan bahasa penghubung antara para insinyur yang merancang dengan operator yang mengerjakan rancangan menjadi produk. Oleh karena itu, perancang dan operator harus menguasai bahasa penghubung ini. Dalam gambar teknik, ada simbol-simbol untuk memudahkan gambar. Jika simbol-simbol ini tidak dipahami oleh operator maka hasil produknya tidak akan sesuai dengan rancangan.

d. Keselamatan kerja dalam proses pengelasan.

Seluruh peserta diberi penjelasan dan diperkenalkan mengenai standar keamanan, keselamatan dan kenyamanan bekerja. Hal ini sangat diperlukan karena sudah menjadi kebiasaan dalam usaha bengkel las pada umumnya yang mengesampingkan keamanan dan keselamatan kerja. Topeng las, masker, sarung tangan dan alat pelindung diri (APD) harus dipakai selama proses pengelasan. 


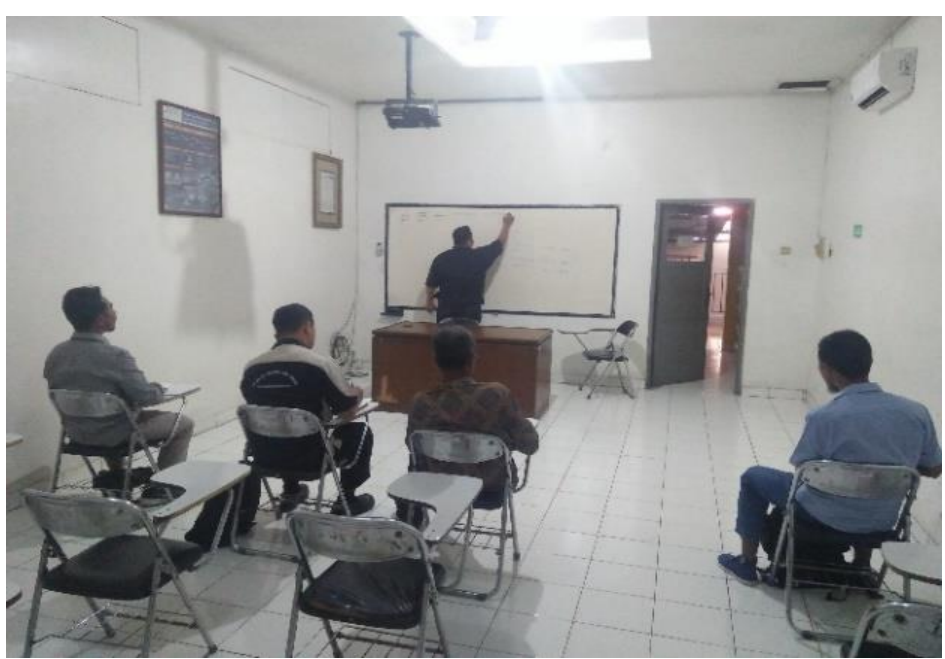

Gambar 3. Pemberian materi teori pengelasan

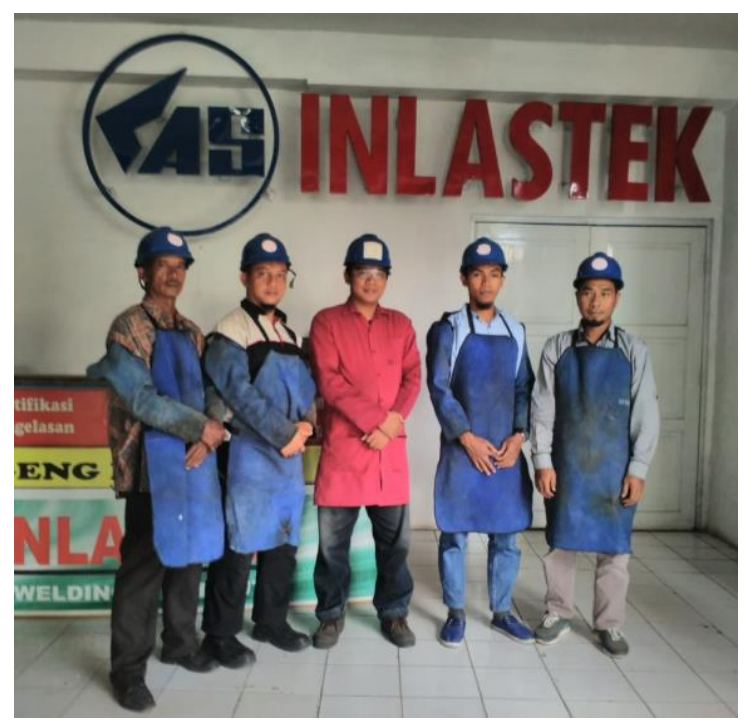

Gambar 4. Peserta pelatihan pengelasan

Tahap kedua dari pelaksanaan pengabdian kepada masyarakat ini adalah pelatihan dan sertifikasi pengelasan. Sertifikat yang dipilih adalah sertifikat juru las ISO 9606-1. Untuk mengeluarkan sertifikat tersebut, Tim Pengabdi UNS wajib menggandeng mitra pelaksana karena UNS bukan lembaga sertifikasi juru las sehingga tidak berhak mengeluarkan sertifikat juru las. Mitra yang diajak bekerja sama adalah Inlastek Welding Institute Surakrta yang merupakan Authorized Training Body (ATB) yang mendapat lisensi dari International Institute of Welding (IIW). Pelatihan juru las ini dilakukan dengan cara mempraktekkan teori yang sudah didapatkan dari tahap sebelumnya. Aktifitasnya dimulai dengan briefing persiapan pelatihan yang meliputi persiapan alat pelindung diri yang diperlukan, pengecekan semua area workshop untuk memastikan semua alat dan mesin berfungsi dengan sempurna dan kemudian mempelajari gambar sambungan las yang diberikan oleh instruktur (Gambar 4, Gambar 5 dan Gambar 6). Selain itu, peserta diberi pemahaman untuk menghitung tingkat keamanan dan kekuatan material sehingga struktur las yang dihasilkan mempunyai kekuatan sambungan di atas titik kritis beban maksimal yang mengenai struktur las tersebut. Symbol las dan pembacaan gambar teknik yang biasa ditawarkan dalam proyek-proyek besar juga diajarkan kepada peserta pelatihan juru las. Pemahaman tersebut kemudian langsung dapat dipraktekan dengan meningkatkan keahlian mengelas dengan posisi-posisi yang cukup sulit berikut inspeksi las seperti diperlihatkan 
oleh Gambar 7. Inspeksi hasil las ini cukup penting sebab dapat menentukan apakah hasil pengelasan memenui kriteria standar yang dipersyaratkan.

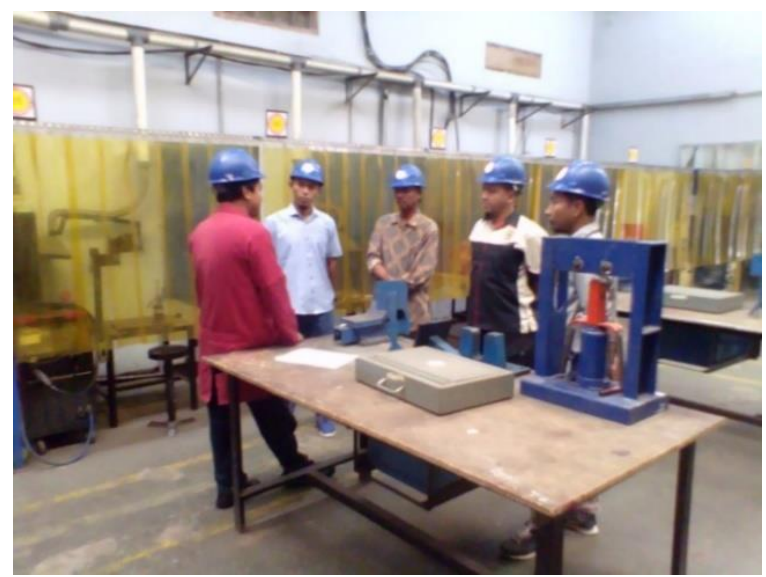

Gambar 5. Briefing pelaksanaan pelatihan las

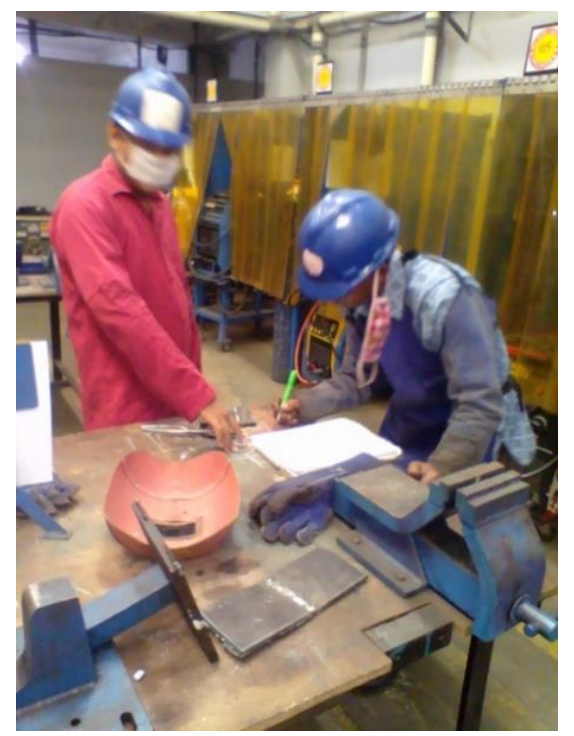

Gambar 6. Praktek pemahaman simbol las dalam gambar

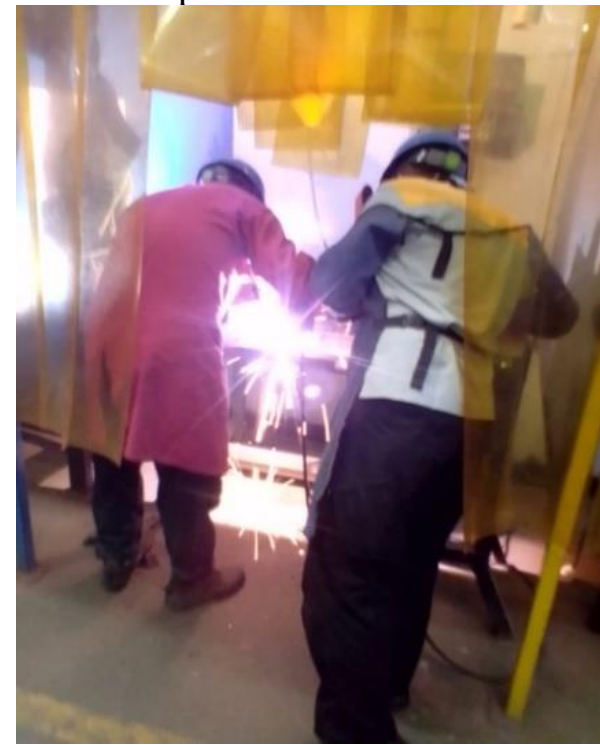

Gambar 7. Pelaksanaan praktek pengelasan logam 


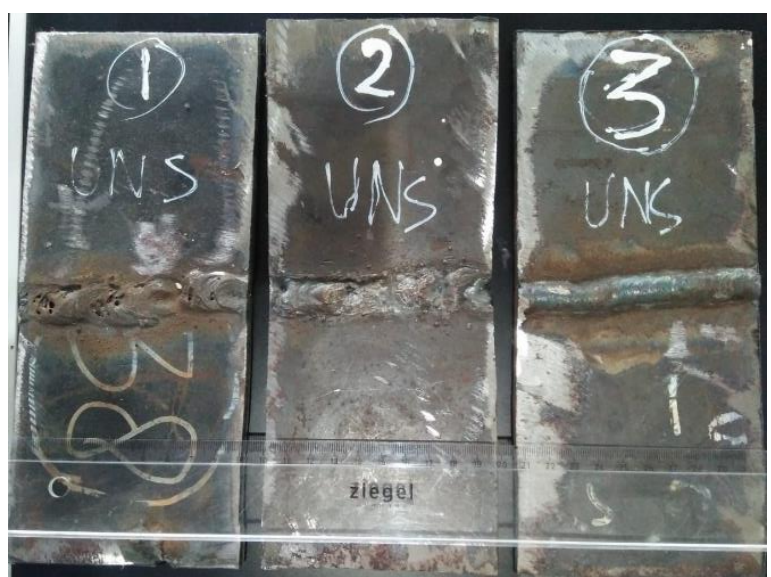

Gambar 8. Hasil pengelasan: 1) sebelum pelatihan, 2) dalam pelatihan 3) setelah pelatihan

Gambar 8 memperlihatkan proses perkembangan hasil pengelasan juru las yang dilatih untuk mengelas plat tebal. Pada awal masuk, peserta pelatihan diminta untuk mengelas plat dengan tebal $10 \mathrm{~mm}$ dan hasilnya ditunjukkan oleh Gambar 8(1), kemudian ditengah-tengah waktu pelatihan peserta pelatihan mengelas plat tebal $10 \mathrm{~mm}$ dan hasilnya ditunjukkan oleh Gambar 8(2). Ada peningkatan penetrasi dan kestabilan manik las. Pada akhir masa pelatihan, peserta pelatihan diminta mengelas plat tebal $10 \mathrm{~mm}$ untuk ujian sertifikasi dan hasilnya ditunjukkan oleh Gambar 8 (3). Empat orang peserta pelatihan yang telah mengikuti ujian dan lolos dalam ujian sertifikasi memperoleh sertifikat las standar internasional seperti terlihat pada Gambar 9.

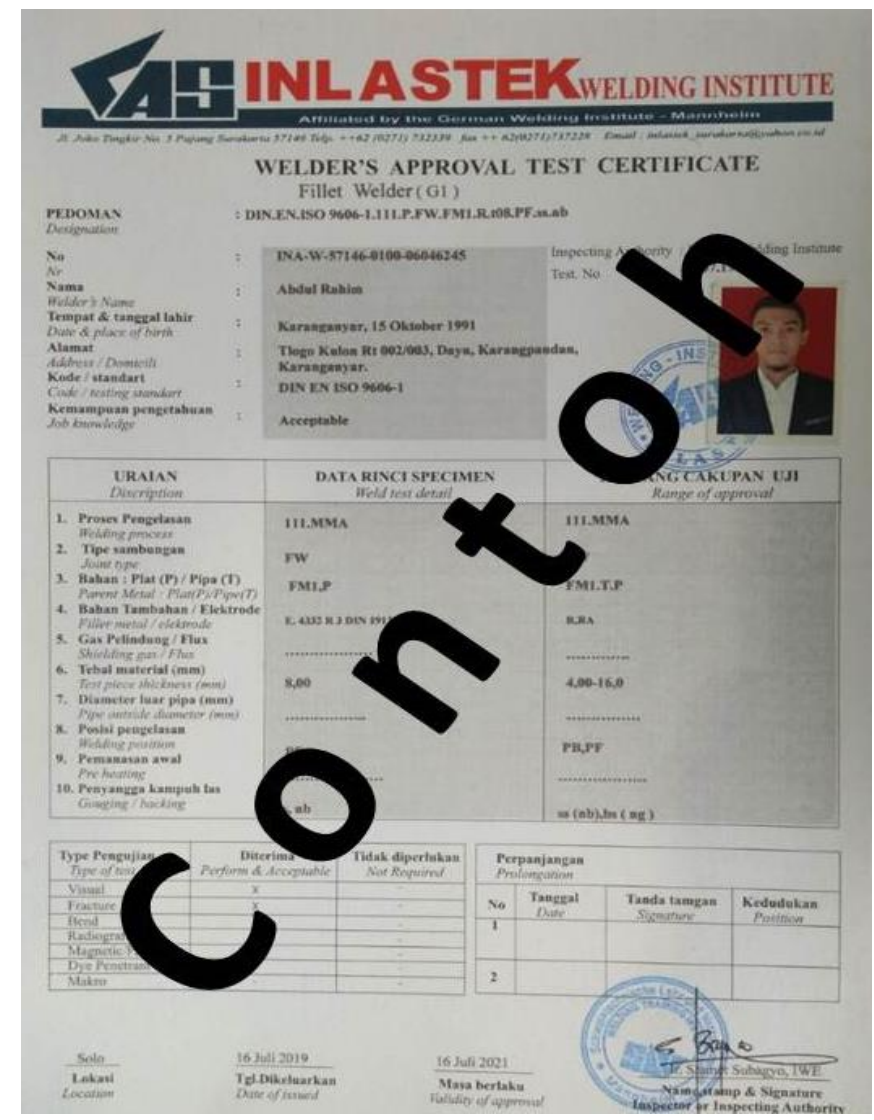

Gambar 9. Contoh sertifikat juru las ISO 9606-1 

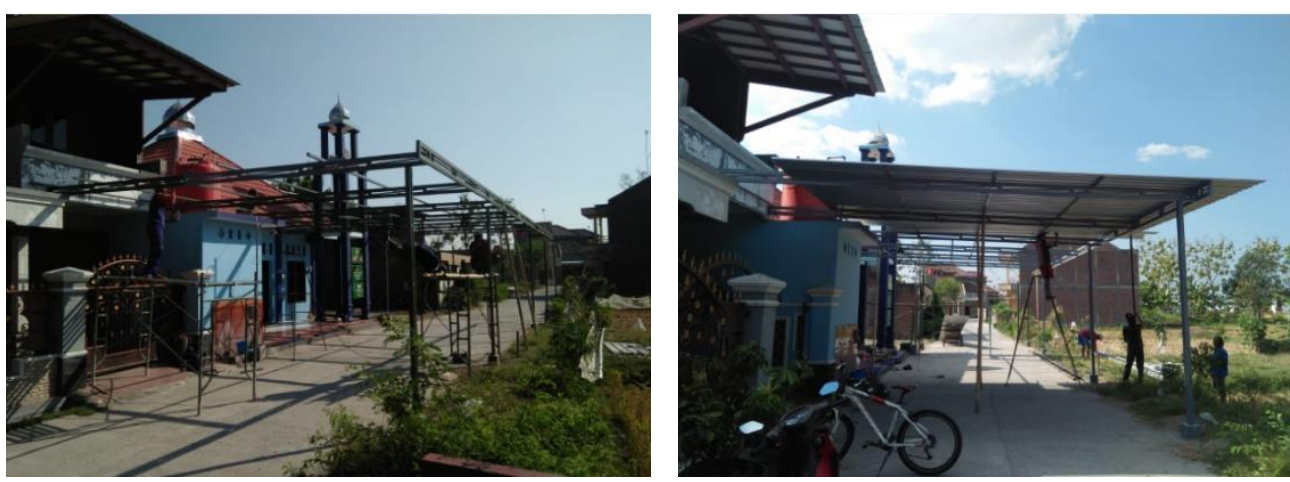

Gambar 10. Pemasangan produk hasil training berupa kanopi yang digunakan oleh mitra ketiga Masjid Fatimah Ar-Royan

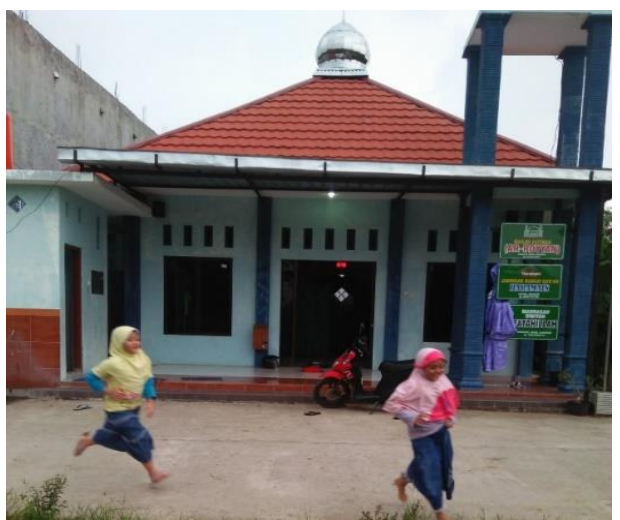

a) Sebelum diberi kanopi

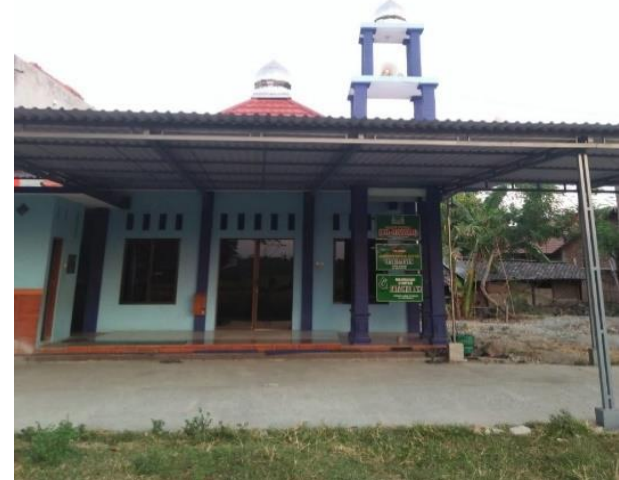

b) Setelah diberi kanopi

Gambar 11. Masjid Fatimah Ar-Royan, Jongkang, Buran, Tasikmadu, Karanganyar

Program Pengabdian pada Masyarakat ini tidak berhenti pada proses pelatihan dan sertifikasi. Namun berlanjut kepada pihak pengguna yang merupakan mitra ke-tiga dari Program Pengabdian kepada Masyarakat yaitu Masjid Fatimah Ar-Royan yang menjadi penerima produk hasil kegiatan pelatihan dan training juru las. Setelah semua peserta pelatihan juru las lulus dan mendapatkan sertifikat, maka mereka besama-sama membuat proyek yanga berupa kanopi masjid. Proyek ini dimulai dari pengukuran, desain dan pelaksanaan pembuatan. Praktek pembuatan kanopi ditunjukkan oleh Gambar 10. Sedangkan hasil pembuatan kanopi ditunjukkan oleh Gambar 11. Pada Gambar 11 tersebut, wajah depan masjid Fatimah Ar-Royyan berubah dari sebelum ada kanopi dan sesudah ada kanopi. Dengan terlaksananya program pengabdian pada masyarakat ini, mitra kedua mendapat ilmu dan pengalaman dalam pemahaman gambar teknik struktur las dan mengelas struktur tersebut dengan standar internasional sedangkan mitra ketiga mendapat produk teknologi tepat guna (TTG) berupa kanopi yang bisa dimanfaatkan untuk jamaah masjid atau untuk umum.

Program Pengabdian pada Masyarakat tahun 2019 ini merupakan program penerapan ilmu dan teknologi di masyarakat. Program ini telah selesai dengan capaian yang cukup baik. Pihak juru las merasa bertambah ilmu dan pengalamannya, pihak takmir masjid juga meraasa senang dengan adanya sumbangan produk pengabdian ini. Karena banyaknya bengkel las di berbagai wilayah, program ini berpotensi untuk dapat dilanjutkan dengan perluasan target mitra yang dapat mengangkat unit usaha pengelasan menjadi kawasan industri manufaktur bidang pengelasan. Dengan kemampuan untuk mengoperasikan dan kemampuan memahami berbagai metode dalam proses pengelasan, maka juru las yang terkumpul dalam kawasan industri manufaktur ini bisa meningkatkan diversifikasi produk, tidak terbatas pada struktur-struktur rumah tangga namun juga bisa membuat produk untuk industri dan lembaga lainnya. 
Dari segi pendalaman materi las, selain keahlian dalam proses pengelasan, bengkel las juga membutuhkan keahlian dalam inspeksi hasil pengelasan. Keahlian inspeksi hasil pengelasan ini bisa digunakan untuk mengukur kualiatas hasil lasan dan memperkirakan terjadinya cacat yang terjadi dalam proses pengelasan. Lebih jauh lagi, keahlian inspeski hasil pengelasan ini dapat digunakan untuk menghitung pengaruh cacat yang terjadi dalam proses pengelasan terhadap umur struktur las dan juga dapat digunakan untuk memutuskan perlu atau tidaknya dilakukan proses lain untuk memperbaiki cacat tersebut atau bahkan harus mengulang proses pengelasan dari awal.

Dalam ilmu perancangan teknik, mitra yang bergerak di bidang pengelasan membutuhkan keahlian di bidang perencanaan. Selama ini proses perencanaan dan desain hanya tergantung pada insting, coba-coba atau trial and error. Selama ini, perencanaan struktur pengelasan hanya tergantung kepada pesanan yang berupa bentuk struktur dan ruang tempat struktur digunakan. Perencanaan struktur las ini belum memperhitungkan faktor keamanan dan kebutuhan materialnya. Seringkali, struktur pengelasan diproduksi berdasarkan pengalaman di tempat lain, sehingga kadangkala desain yang dibuat sangat aman dengan dimensi yang lebih besar dari perhitungan teknis dan ini akan menyebabkan kebutuhan material menjadi sangat banyak dan struktur menjadi berat.

Keahlian perancangan yang seharusnya dipahami oleh juru las rumah tangga adalah berupa keahlian menggambar teknik, perhitungan kekuatan material dan desain. Keahlian menggambar teknik dalam proses perencanaan sangat penting untuk mengukur ketercapaian suatu produk perancangan terhadap parameter desain dan fungsi produk, sehingga perkiraan kebutuhan material dan dana yang dibutuhkan dapat ditentukan dengan tepat dan akurat. Kemampuan menggambar teknik ini membutuhkan perangkat komputer dan keahlian pengoperasian software menggambar. Saat ini banyak software open source yang menyediakan program menggambar gratis untuk digunakan siapa saja. Tentu saja, pelatihan dan praktek dengan pendampingan dari instruktur mutlak diperlukan dalam proses meningkatkan pemahaman desain kepada juru las. Analisa perhitungan biasanya terintegrasi langsung di dalam software sehingga juru las tidak perlu melakukan perhitungan rumit seperti di kampus tetapi juru las cukup mengetahui parameter faktor yang berpengaruh dan bisa mengoperasikan software.

\section{KESIMPULAN}

Kegiatan pengabdian pada masyarakat yang berupa pelatihan, sertifikasi dan pengerjaan proyek percontohan telah selesai dilaksanakan. Sebanyak empat peserta yang merupakan pemilik bengkel las di wilayah Jaten, Karanganyar, Jawa Tengah, mengikuti program ini. Kegiatan pelatihan dan sertifikasi dilakukan selama dua hari di Inlastek Welding Institute Surakarta, sedangkan kegiatan pengerjaan proyek percontohan dilakukan di Masjid Fatimah Ar Royyan, Jaten, Karanganyar. Hasil pengelasan sebelum pelatihan dan sesudah pelatihan menunjukkan bahwa pelatiahan dan sertifikasi ini mampu meningkatkan kualitas hasil pengelasan. Kampuh sambungan las setelah sertifikasi terlihat lebih stabil, halus dan tidak ada cacat pengelasan. Dengan hasil tersebut, produk las hasil juru las-juru las yang tersertifikasi ini akan lebih berkualitas dan mempunyai factor keamanan yang lebih baik.

\section{UCAPAN TERIMA KASIH}

Terimakasih diucapkan kepada Universitas Sebelas Maret Surakarta yang telah memberi dukungan dana pengabdian ini melalui hibah Program Kemitraan Masyarakat (PKM) PNBP UNS tahun anggaran 2019 dengan kontrak Nomor 517/UN27.21/PM/2019. 


\section{DAFTAR PUSTAKA}

[1] Kurniawan, Ipung. "Pelatihan Las Listrik Dasar untuk Masyarakat Usia Produktif Lingkungan Rw 10 Desa Sidanegara Kecamatan Cilacap Tengah Kabupaten Cilacap." Journal of Appropriate Technology for Community Services 1, no. 2 (2020): 91-99.

[2] K. Easterling, Introduction to the Physical Metallurgy of Welding, Butterworth Heinemann, 1992.

[3] S. Kou, Welding Metallurgy, Wiley Pub., 2003.

[4] Azwinur, Azwinur, Marzuki Marzuki, and Anwar Anwar. "Pelatihan Las Argon Untuk Pekerja Usaha Bengkel Las Masyarakat Gampong Mesjid Punteuet Dalam Upaya Meningkatkan Pendapatan Masyarakat Masyarakat." Jurnal Vokasi 2, no. 1 (2018): 40-44.

[5] Amalia, Iin, Irwan Djumena, and Suherman Suherman. "UUpaya Instruktur dalam Memberdayakan Warga Binaan melalui Pelatihan Las Smaw." Journal of Nonformal Education and Community Empowerment 2, no. 2 (2018). 